\title{
Akut myeloid leukémiával 2007-2017 között a Semmelweis Egyetem I. sz. Belgyógyászati Klinikán kezelt betegek adatainak elemzése
}

\author{
Raska Alexandra ${ }^{1, *}$, Krizsán Szilvia ${ }^{2}$, Nagy Zsoltt ${ }^{1}$, Demeter Judit ${ }^{1}$, Bödör Csaba ${ }^{2}$, \\ Tárkányi Ilona ${ }^{1, @ ~}$
}

\author{
${ }^{1}$ Semmelweis Egyetem, I. sz. Belgyógyászati Klinika, Budapest \\ ${ }^{2}$ Semmelweis Egyetem, I. sz. Patológiai és Kísérleti Rákkutató Intézet, \\ MTA-SE Lendület Molekuláris Onkohematológia Kutatócsoport, Budapest
}

\begin{abstract}
Bevezetés: Az akut myeloid leukémia diagnosztikája és kezelése a megfelelően felkészült központokban is folyamatos követést igényel, hogy visszajelzést kapjunk a kezelt betegpopulációról, illetve a terápia eredményességéről. Célkitüzés: Jelen tanulmányunk célja a 2007 és 2017 között a Semmelweis Egyetem I. sz. Belgyógyászati Klinikán akut myeloid leukémiával diagnosztizált betegek adatainak elemzése volt. Módszer: 239 beteg adatait dolgoztuk fel retrospektíven. Az egyes alcsoportokat a legújabb nemzetközi ajánlásoknak megfelelően soroltuk be. A statisztikai analízis IBM SPSS 24 statisztikai programmal történt. Eredmények: A nők és férfiak aránya közel azonos volt. Diagnóziskor a betegek medián életkora 67 évnek adódott, és a 60 év felettiek csaknem kétszer többen voltak (162 fö), mint a 60 év alattiak (77fö). Az European Leukemia Net beosztás szerint a kedvező rizikójú csoportba 11\%, az átmeneti rizikójúba 47\%, a kedvezőtlen prognózisúba $26 \%$ tartozott, míg a betegek 16\%-át hiányzó adatok miatt nem lehetett besorolni. 119 beteget kuratív célú nagy dózisú kemoterápiával, míg 104-et palliatívan kezeltünk, 16 beteg csak szupportív kezelést kapott. A kuratívan kezelt betegek kétéves összesített túlélése $41,7 \%$, az ötéves $26 \%$-ra volt tehető. A palliatívan kezeltek kétéves összesített túlélése 7,6\% volt: ezen betegeknél a demetiláló és citoreduktív terápiát kapott csoportok medián túlélésében szignifikáns eltérést tapasztaltunk ( 10 vs. 2 hónap). A hemopoetikus őssejtátültetésen átesett 31 beteg átlagéletkora 49 év volt, többségüket (23 fö) HLA-egyező idegen donorral transzplantálták, a betegek hároméves túlélése $48 \%$ volt. Következtetés: Tanulmányunkban a klinikánk elmúlt 11 évében gondozott akut myeloid leukémiás eseteit dolgoztuk fel. Kezelési eredményeink közelítenek a nemzetközi irodalomban ismertetett arányokhoz, követik az új terápiás stratégiákkal elérhető javuló trendeket is, így összességében megfelelnek a modern kezelési követelményeknek.
\end{abstract}

Kulcsszavak: akut myeloid leukemia, túlélés, remisszió, kemoterápia

\section{Evaluation of acute myeloid leukemia patients treated between 2007 and 2017 at the 1st Department of Internal Medicine, Semmelweis University}

\begin{abstract}
Introduction: Diagnostics and treatment of acute myeloid leukemia requires continuous surveillance even in highly experienced hematological centers, since we need feedback about the treated patient population and the results of our therapeutic approaches. Aims: Our goal was to evaluate data of the patients treated with acute myeloid leukemia between 2007 and 2017 at the 1st Department of Internal Medicine, Semmelweis University. Methods: We retrospectively analyzed data of 239 patients. Classifications were based on recent international recommendations. Statistical analyses were performed using the SPSS software (ver. 24.0). Results: The number of male and female patients was nearly equal. Average age at diagnosis was 67 years, number of patients over 60 was almost double (162) compared to those below 60 years (77). $11 \%$ belonged to favorable, $47 \%$ to intermediate and $26 \%$ to adverse risk category according to European Leukemia Net classification, $16 \%$ of the patients could not be classified due to incomplete data. 119 patients were treated with high-dose chemotherapy with curative intention, 104 patients underwent palliative therapy and 16 individuals
\end{abstract}

\footnotetext{
@ Levelezési cím: Dr. Tárkányi Ilona, Semmelweis Egyetem, I. sz. Belgyógyászati Klinika; Tel: +36-20-6663-626;

E-mail: ilona_tarkanyi@yahoo.com

* A szerző jelenlegi munkahelye: Semmelweis Egyetem, III. sz. Belgyógyászati Klinika
} 
received only best supportive care. Overall survival rate of patients treated with curative intention was $41.7 \%$ at two years and $26 \%$ at five years. Two-year overall survival of individuals receiving palliative therapy was $7.6 \%$ : among these patients we could observe a significant difference in median survival when subgroups treated with demethylating agents and cytoreductive therapy was compared ( $10 \mathrm{vs} .2$ months). Average age of the 31 patients undergoing hematopoietic stem cell transplantation was 49 years, the majority (23 patients) of them was transplanted with an HLA-matched unrelated donor. Three-year overall survival in this population was $48 \%$. Conclusions: We evaluated acute myeloid leukemia cases seen in our clinic in the past 11 years. Our treatment results were close to international reported response rates and followed the improving results seen with new therapeutic strategies, thus comply with the requirements of modern clinical practice.

Keywords: acute myeloid leukemia, survival, remission, chemotherapy

(Beérkezett: 2019. október 23.; elfogadva: 2019. november 11.)

\begin{abstract}
Rövidítések
AML = akut myeloid leukémia; BCL-2 = B-cell lymphoma 2; $\mathrm{CEBPA}=\mathrm{CCAAT} /$ Enhancer Binding Protein Alpha; $\mathrm{CR}=$ komplett remisszió; ELN = Európai Leukemia Net; FLT3 = fms-szerü tirozin-kináz; HLA = humán leukocyta antigén; IDH = izocitrát-dehidrogenáz; ITD = (internal tandem duplication $)$ belső tandem duplikáció; MDS = myelodysplasiás szindróma; MPN-BP = myeloproliferatív neoplázia blasztos fázis; $\mathrm{MRD}=$ minimális/mérhető reziduális betegség; MUD = (matched unrelated donor) egyező idegen donor; NPM1 = nucleophosmin 1 ; OS = (overall survival) összesített túlélés; RIC = redukált intenzitású kondicionálás; TKD = tirozin-kináz domén; WHO $=$ (World Health Organization) Egészségügyi Világszervezet
\end{abstract}

\section{Bevezetés}

Az akut myeloid leukémia jelenleg is a legnagyobb mortalitással járó hematológiai malignitások közé tartozik, kezelése nagy kihívást jelentő feladat [1]. Minden korcsoportban előfordul, így a fiatal, nagy dózisú kemoterápiára alkalmas betegek esetén a teljes gyógyulásra kell törekednünk, lehetőség szerint alacsony toxicitású, hosszú távú egészségkárosodással nem járó kezelési modalitásokkal. A klinikai jelentősége emellett azért is figyelemre méltó, mivel idős korban az incidenciája nő, sajnálatos módon a kedvezőtlen prognosztikájú (MDS, illetve terápiaasszociált, kedvezőtlen cito- és molekuláris genetikájú) csoportok túlsúlyával. Ezen betegek kezelése egyre nagyobb feladatot ró a hematológusokra [2]. Az AML diagnosztikája és kezelése a megfelelően felkészült központokban is folyamatos követést igényel, így beteganyagunk statisztikai célú feldolgozása jelentős, mert visszajelzést kapunk a terápiás megközelítéseink eredményességéről és a fejlesztési lehetőségekről.

\section{Módszerek}

Retrospektív vizsgálatunkban a Semmelweis Egyetem I. sz. Belgyógyászati Klinika Hematológia Osztályán 2007. január és 2017. december között akut myeloid leukémiával diagnosztizált 239 beteg adatait dolgoztuk fel. Az AML diagnózisa minden esetben az Egészségügyi Világszer- vezet (World Health Organization, WHO) kritériumai szerint történt [3]. A fenti időszakban klinikánkon további 17, akut promyelocytás leukémiával diagnosztizált esetet kezeltünk, ezek adatait azonban vizsgálatunk nem tartalmazza, mivel kezelésük és prognózisuk is eltérő a többi leukémia-altípusétól [4].

$\mathrm{Az}$ adatgyújtés a Semmelweis Egyetem informatikai rendszerében tárolt betegadatok feldolgozásával történt. A hemopoetikus őssejtátültetésen átesett betegek transzplantációhoz kapcsolódó adatait a Dél-pesti Centrumkórház Hematológiai Osztályán gyüjtöttük ki.

A szövettani, illetve cito- és molekuláris genetikai vizsgálatok rendre a Semmelweis Egyetem I. sz. Patológiai és Kísérleti Rákkutató Intézetben történtek. Molekuláris genetikai adatainkat az ELN (European Leukemia Net) ajánlásának megfelelően kiegészítettük a 2013 után végzett FLT3-ITD (fms-szerủ tirozin-kináz internal tandem duplication) mutáció vizsgálattal pozitívnak értékelt minták vad és mutált allélarányaival, az archivált genomiális DNS-minták felhasználásával [5]. Az IDH1 és $I D H 2$ (izocitrát-dehidrogenáz 1 és 2) mutációinak vizsgálata szintén a feldolgozásra alkalmas archivált DNS-mintákból történt.

A betegdokumentációból rögzítésre került: az életkor, a nem, a diagnózis pontos ideje, az alkalmazott kezelések és terápiás válaszok, a releváns anamnesztikus adatok, továbbá a hisztológiai, áramlási citometriai, cito- és molekuláris genetikai eltérések. Ezeket a paramétereket felhasználva a betegeket alcsoportokba osztottuk a 2016-os módosított WHO klasszifikáció, illetve a 2017-es ELN standardizált rizikóbesorolás alapján. Az egyes alcsoportok analízisét az IBM SPSS 24 statisztikai programmal végeztük, a túlélések összehasonlítása Log Rank teszttel történt.

\section{Eredmények}

\section{Betegek jellemzöi, WHO csoportok}

A vizsgálatunkban elemzett 120 férfi és 119 nő medián életkora a kórkép diagnózisának idején 67 év (18-89) volt. Kiemelendő, hogy hatvan év felett közel kétszer annyi be- 


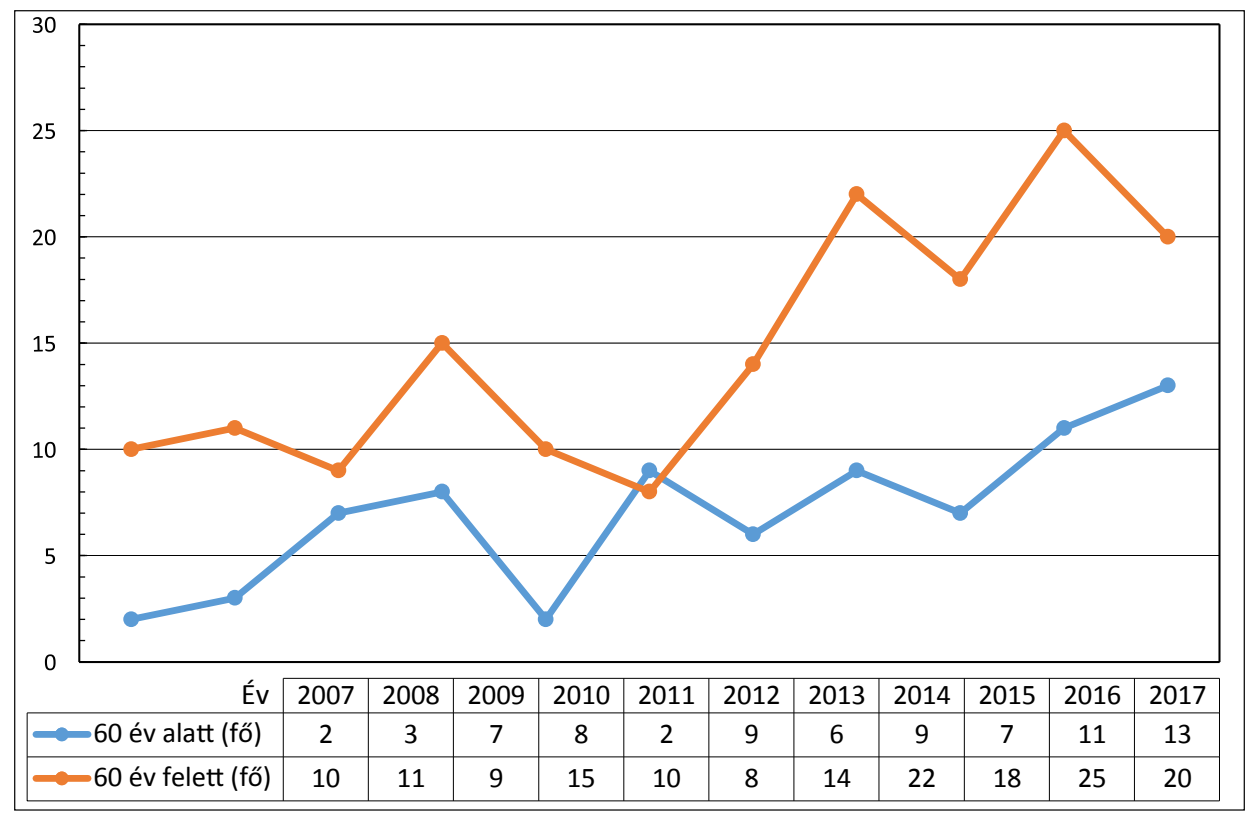

1. ábra. Újonnan diagnosztizált betegek száma a 60 év alatti és feletti korcsoportban évenkénti bontásban a Klinika beteganyagában

teget (162 fö) kezeltünk a Klinikán a tizenegy év során, mint hatvan évnél fiatalabbat (77 fö), továbbá az újonnan diagnosztizált betegek száma az évek során emelkedő tendenciát mutatott (1. ábra).

A WHO osztályozása szerint a visszatérő genetikai eltéréssel járó csoportba 36, máshogyan nem osztályozható kategóriába 64, myelodysplasiához (MDS) társult AML 100, kevert fenotípusú leukémia 5, myeloid sarcoma 9, terápiaasszociált leukémiákhoz sorolhatóan 6 beteg tartozott. 19 betegünknél a szekunder AML Philadelphianegatív myeloproliferatív neoplázia blasztos fázisaként (MPN-BP) alakult ki (2. ábra). Az MDS-asszociált AML esetek közül 36 betegnél már korábban igazolták csontvelő-biopsziával a myelodysplasiát, illetve 6 betegnél a krónikus myelomonocyter leukémiát, míg 58 esetnél a rendelkezésünkre álló betegdokumentációk alapján először az AML diagnózisakor igazolódtak a diszplasztikus morfológiai, komplex citogenetikai eltérések. Myeloproliferatív betegségből transzformálódott leukémiát 19 esetben találtunk, ebböl 6 polycythemia vera, 5 esszenciális thrombocytosis, 2 primer myelofibrosis, 6 nem besorolható myeloproliferatív betegség volt. A terápiaasszociált csoportban az AML kialakulásának hátterében emlőtumor, tüdőcarcinoma, rectumcarcinoma, Hodgkin-lymphoma, és hólyagcarcinoma miatti kemoterápia vagy irradiáció volt felfedhető.

\section{Betegek patológiai eltérései}

A betegek patológiai leleteit feldolgozva összesen 189 esetben volt elérhető a citogenetikai vizsgálat eredménye. Mintegy 20\%-ban voltak jelen a kedvezőtlen citogenetikai eltérések [komplex karyotípus, del(5), del(7)]. Normális karyotípussal járó betegség a betegek $44 \%$-ában volt megfigyelhető. Kedvező prognózisú, visszatérő kromoszómarendellenességek $[(t 8 ; 21)$ és inv(6)] az esetek igen kis

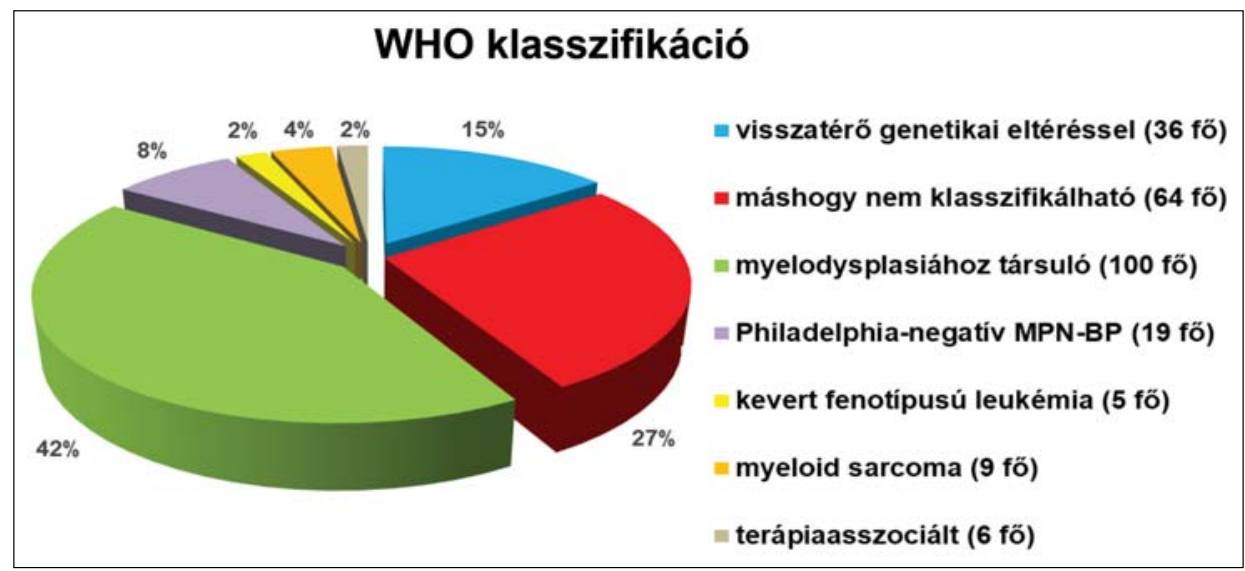

2. ábra. Az akut myeloid leukémia altípusainak gyakoriság szerinti megoszlása az Egészségügyi Világszervezet (WHO) 2016-ban megjelentetett osztályozása alapján 


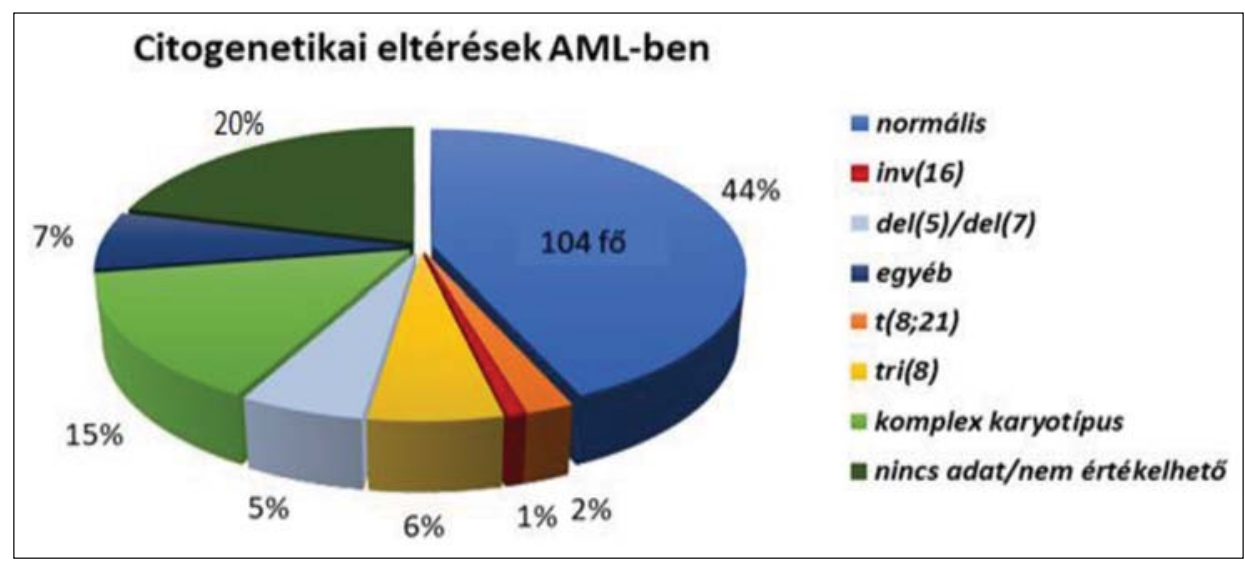

3. ábra. Citogenetikai eltérések előfordulási gyakorisága akut myeloid leukémiás (AML) beteganyagunkban

részében kerültek leírásra (3\%). 13\%-ban intermedier csoportba sorolható citogenetikai eltéréseket találtunk, a betegek 20\%-ánál pedig nem állt rendelkezésre értékelhetô minta (3. ábra).

Molekuláris genetikai vizsgálat összesen 119 betegnél történt. Az elvégzett molekuláris vizsgálatok száma az elmúlt évtizedben folyamatosan emelkedett: míg 20072008-ban csupán az esetek mintegy 15\%-ában történt meg, az utolsó öt évben a betegek 62\%-ában elvégezték. Amennyiben a kuratív szándékkal kezelt betegeket nézzük, 2013-2017 között átlagosan már több mint 80\%-ban megtörtént a teljes citogenetikai és molekuláris genetikai kivizsgálás. A jó prognózissal társuló $N P M 1$ - és $C E B P A$ mutációk az esetek 14\%-ában, míg a rossz vagy átmeneti prognózist jelölő FLT3-mutáció önmagában vagy NPM1gyel kombinálva 16\%-ban volt detektálható (4. ábra). A 28 FLT3-ITD-mutáció-pozitív beteg mintái közül a 2013. évet követően 21 esetben állt rendelkezésre DNSminta az allélarányok meghatározásához. Az utólagosan meghatározott allélarányok a következőképp alakultak: 0,5 alatti mutáns/vad (alacsony) allélaránnyal és NPM1pozitivitással 7 beteg, NPM1-mutáció nélkül 10 beteg;
0,5 feletti mutáns/vad (magas) allélaránnyal és NPM1mutációval 2, míg NPM1-mutáció nélkül 3 beteg. $\mathrm{Az}$ IDH-mutáció státusz retrospektív meghatározására a 239 beteg mintáiból 50 esetben (20,9\%) volt lehetőség, ezek közül IDH1-mutációt 3 beteg (6\%), IDH2-mutációt 6 beteg (12\%) esetében mutattak ki. Ez megfelel a nemzetközi adatoknak, mivel az IDH1-mutáció előfordulását az AML-es betegekben 6-10\%-ra, míg az IDH2-mutációét 9-13\%-ra teszik [6]. A Semmelweis Egyetem I. sz. Patológiai Intézetének közelmúltban megjelent közleménye közel azonos időintervallumban 10 hazai hematológiai egység által beküldött minták elemzését tartalmazza [7]. A közölt felmérés alapján a multicentrikus adatokkal öszszehasonlítva klinikánkon alacsonyabb arányban fordultak elő kedvező citogenetikai eltéréseket hordozó betegek, míg a komplex citogenetikai eltérést hordozók aránya közel azonos értéket mutatott [8,9]. Összevetve a fenti genetikai eltéréseket a betegek $11 \%$-a a kedvező $(n=27)$, $48 \%$-a az átmeneti $(n=114), 26 \%$-a a kedvezőtlen $(n=63)$ ELN rizikócsoportba tartozott, továbbá $15 \%$-ukat a hiányos adatok miatt nem lehetett besorolni $(n=35)$.

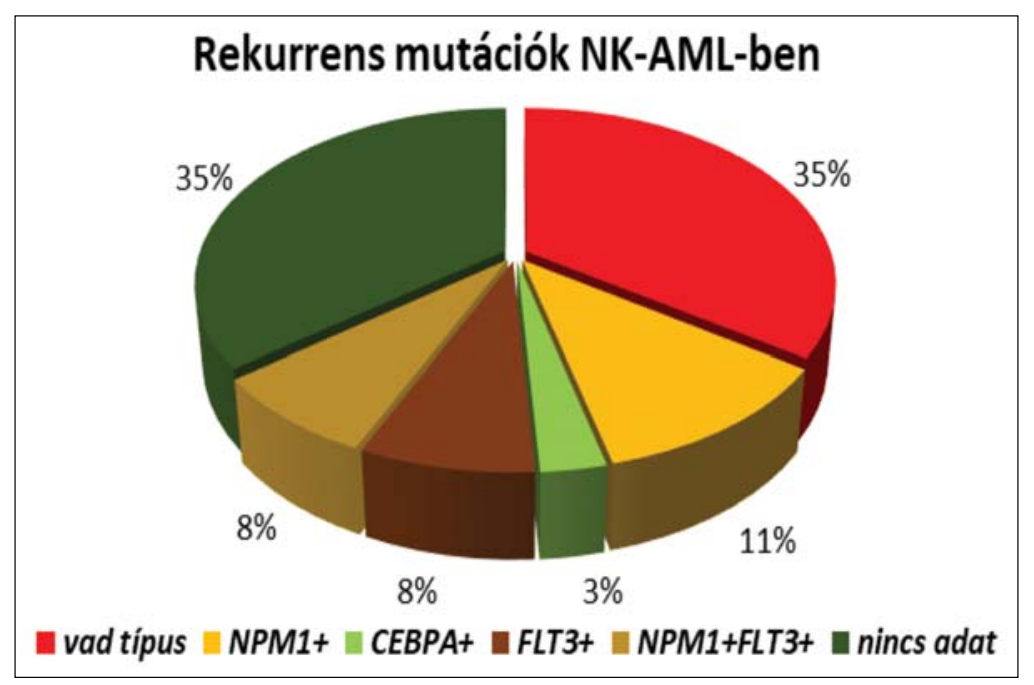

4. ábra. Visszatérő mutációk előfordulási gyakorisága normál karyotípusú akut myeloid leukémiában (NK-AML) szenvedő betegeinkben 


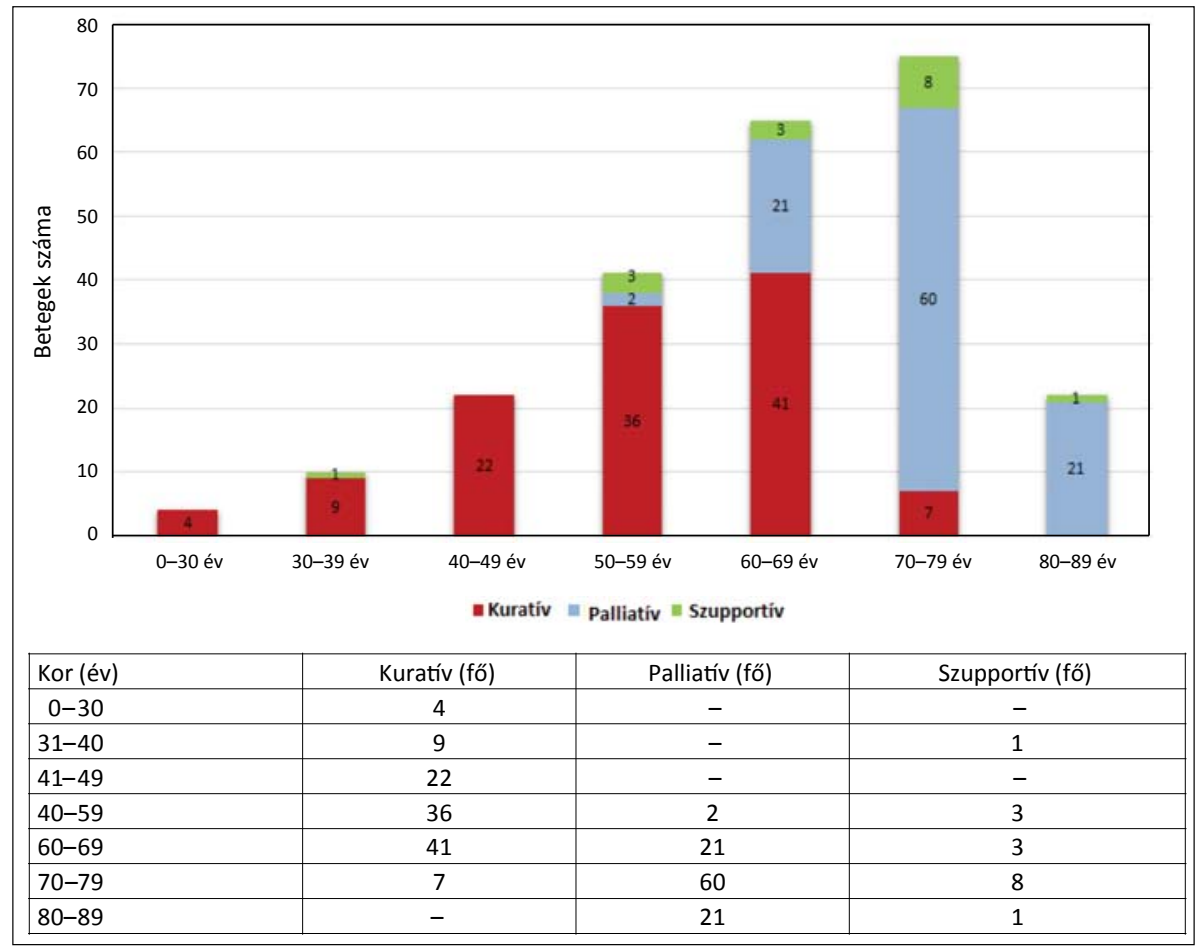

5. ábra. Az alkalmazott terápiás megközelítések korcsoport szerint

\section{Terápiás modalitások korcsoportok szerint}

A kutatásban 119 betegek részesült nagydózisú kemoterápiában, 104 fó palliatív kezelést kapott, 16 esetben csak szupportív kezelésre volt lehetőség.

A korösszetétel és a terápiás választás tekintetében a 60 év alatti korcsoportban szinte minden esetben (71/77; $92,2 \%)$, a 60 év felettiek közel egyharmada részesült indukciós kezelésben $(48 / 162 ; 29,6 \%)$. Irodalmi adatok alapján az idős, de jó általános állapotú, kevés komorbiditással rendelkező betegeknél bizonyítottan a túlélés nö- vekedése várható az agresszív terápiás megközelítéstől, ezért ebben az esetben ez az elsődlegesen választandó [10]. Figyelemre méltó, hogy a 60-69 év közötti korcsoportban a betegek nagyobb része kapott nagy dózisú kemoterápiát $(41 / 65 ; 63,1 \%)$, mint palliatív kezelést, míg a $70-75$ éves korosztály csupán kis része $(7 / 75 ; 9,3 \%)$ részesült nagy dózisú indukciós kezelésben. A 7 betegből 2 esetben értünk el komplett remissziót, 2 beteg terápiarezisztens volt, így ezt követően palliatív kezelést kapott, 3 beteg az apláziás időszakban hunyt el (5. ábra).

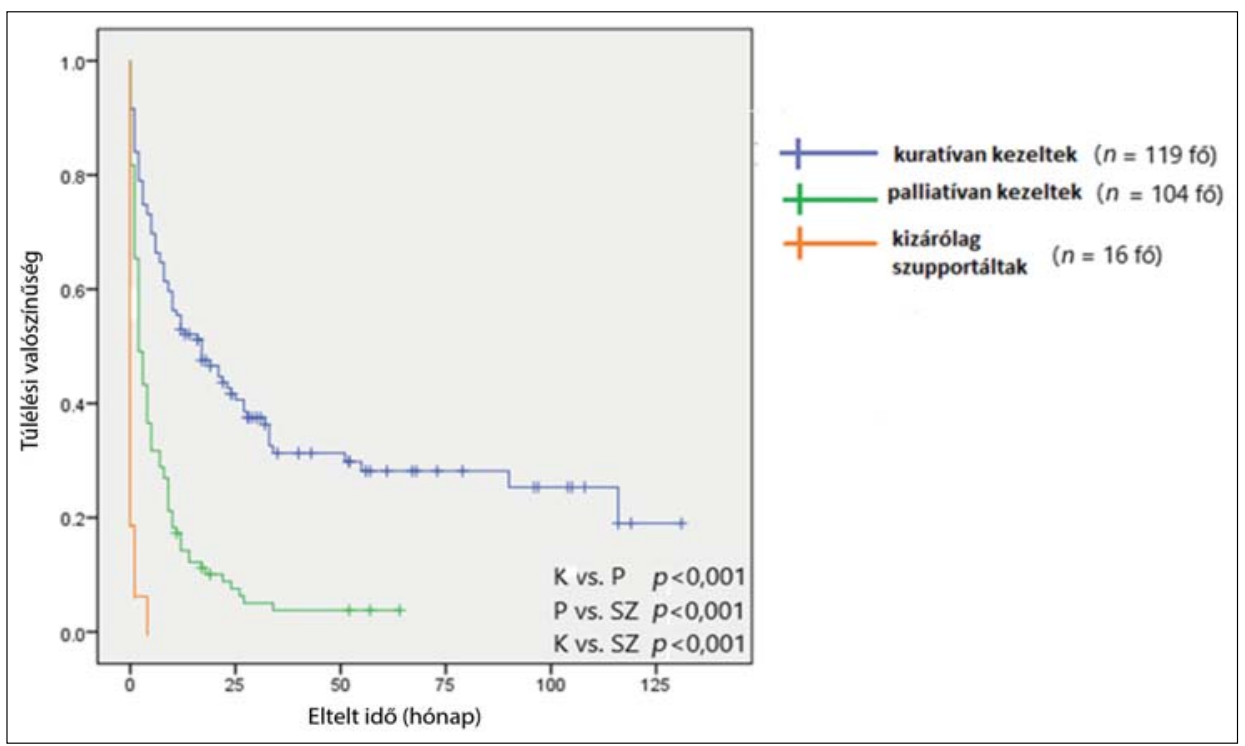

6. ábra. Összesített túlélési valószínűségek kezelési megközelítés szerint. (K: kuratív; P: palliatív, SZ: kizárólag szupportív kezelésben részesült betegek) 


\section{Összesitett túlélések és terápiás válaszok az egyes alcsoportokban}

A továbbiakban az egyes kezelési modalitások összesített túlélésre gyakorolt hatását vizsgáltuk. A kuratívan kezelt betegek körében a 2 éves OS (overall survival, összesített túlélés) $47,7 \%$, az 5 éves OS $26 \%$ volt, míg a palliatív kezelésben részesülteknél a 2 éves OS 7,6\%-nak adódott. A csak szupportív kezelésben részesültek medián túlélése nem érte el az egy hónapot (0,37 hó) (6. ábra).

A kuratív szándékkal kezelt betegek közül a három prognosztikai csoportban nem tért el szignifikánsan a komplett remissziót elérők aránya, azonban a túlélésük tekintetében már szignifikánsan elkülönült a három csoport. Két év elteltével a kedvező kórjóslatú betegek 64,7\%-a, az átmeneti rizikójú csoport 45\%-a volt életben, míg a kedvezőtlen rizikójú csoportban a kétéves összesített túlélés 23,8\%-ra volt tehető (7. ábra). A 60 év alatt és 60 év feletti korcsoportokban a komplett remissziót elérő betegek aránya között nem volt szignifikáns eltérés ( $p=$ 0,08), továbbá túléléseik között sem találtunk szignifikáns eltérést $(p=0,129)$ : a fiatalabb korcsoportban a 2 éves OS: 42,3\%, míg az idősebbek körében ez 37,5\%-nak adó$\operatorname{dott}$ (8. ábra).

A palliatívan kezelt betegek körében alkalmazott demetiláló kezelés átlagosan 8 hónappal hosszabbította meg a betegek medián teljes túlélését a konvencionális citoredukciós terápiában részesültekéhez képest. Emellett a betegek 2 éves túlélései is szignifikánsan javultak $(p<$ 0,001) (9. ábra). A fentiek miatt megvizsgáltuk, hogy hogyan változtak a demetiláló kezelés bevezetése óta a Klinikán palliatívan kezelt betegek összesített túlélései. Az elmúlt 4 év során - a demetiláló szerek elterjedésével - szignifikánsan jobb lett a palliációban részesültek túlélése a 2014 előtti viszonyokhoz képest $(p=0,004)$ (10. ábra).

\section{Össejt-transzplantáción átesett betegek jellemzői}

A hemopoetikus őssejtátültetésen átesett 31 beteg átlagos életkora 49 év (18-64) volt, ebből 6 páciens volt 60 évnél idősebb. A pretranszplantációs betegségstátusz tekinte-

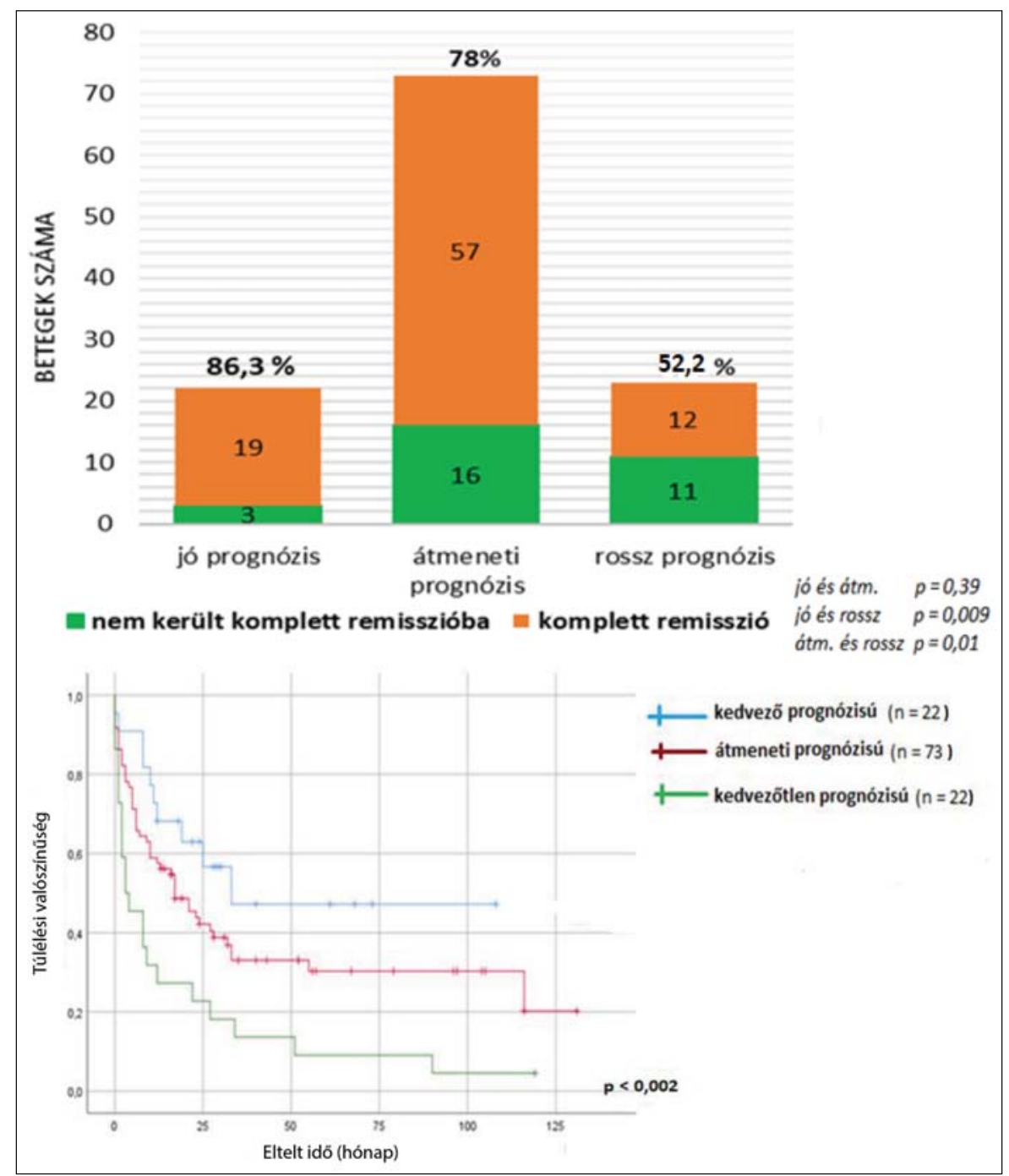

7. ábra. Komplett remisszió és összesített túlélés prognosztikai csoportok szerint 


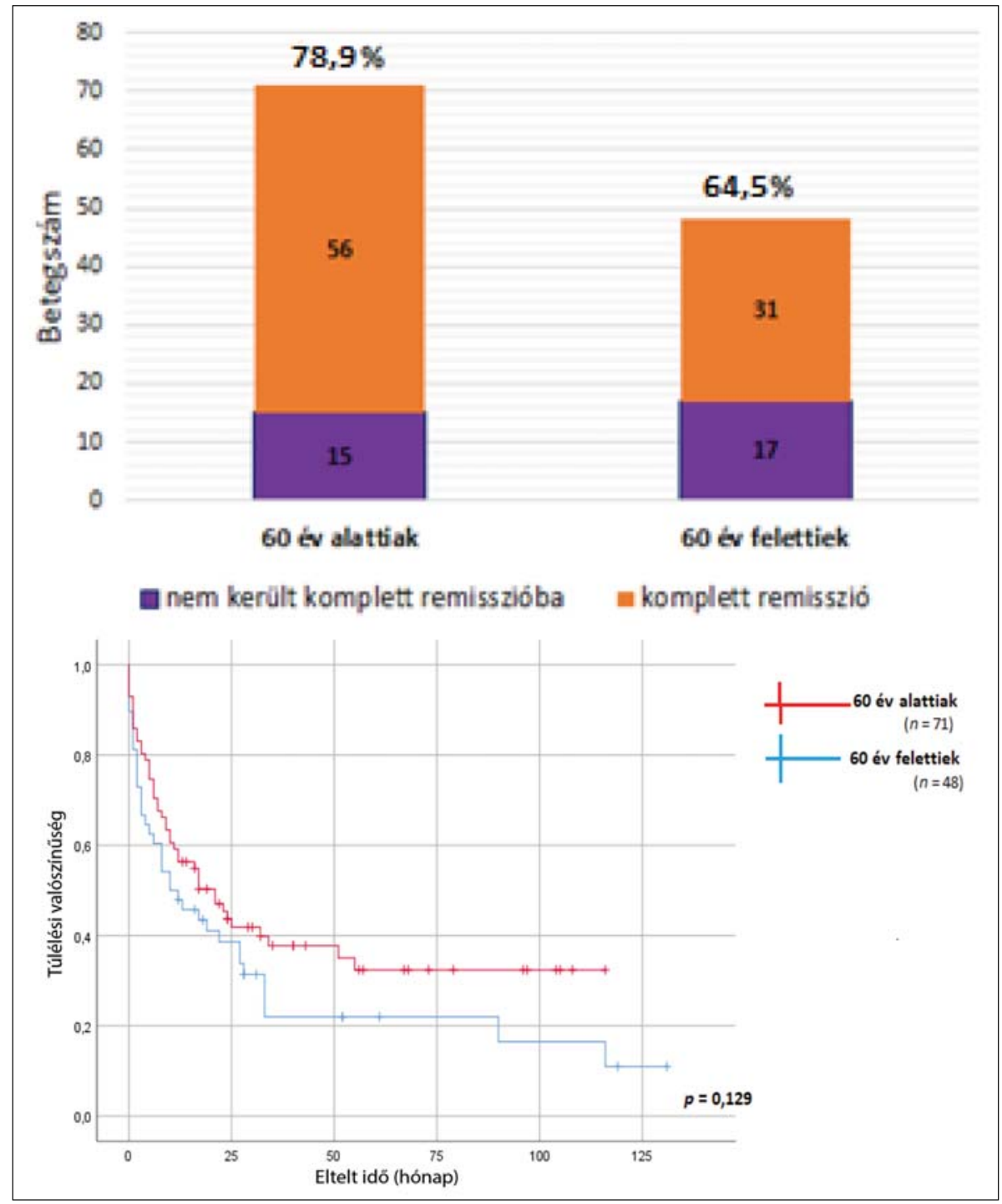

8. ábra. Komplett remisszió és összesített túlélés életkor szerint beteganyagunkban

tében a legoptimálisabb első komplett remisszióban 26 beteget transzplantáltak, 5 betegnél az AML relapszusát követően végezték az őssejtátültetést. Donorválasztás tekintetében HLA-identikus testvérdonorral, a szakirodalomban leírt 30\%-tól eltérően, a betegek mindössze 16\%-át (5 fó) transzplantálták [11]. Sajnos a hazánkban észlelt csekély őssejtdonációs szándék itt is tetten érhető, több alkalommal tapasztaltuk a potenciális donorok elzárkózását a HLA-tipizálástól. HLA -dentikus vagy jó egyezést mutató HLA tulajdonságú idegen donort (MUD-matched unrelated donor) 22 esetben és haploidentikus szülőtől származó donort 1 esetben használtak. Emellett 2008 és 2009 között két betegnél autológ átültetés történt. 19 beteg myeloablatív, 12 beteg redukált intenzitású kondicionáló (RIC) kezelést kapott. A mortalitási mutatók a nemzetközi arányokhoz közelítenek: a transzplantációt követő 3 éves OS: $48 \%$, a medián túlélés pedig $20 \pm 13,8$ hónap volt (átlagos követési idő: 90 hónap) [12]. A poszttranszplantációs halálozásért $40 \%$-ban a relapszus, $60 \%$-ban egyéb ok volt felelős - döntő többségben infekciós szövődmények.

\section{Megbeszélés}

Vizsgálatunkban a Semmelweis Egyetem I. sz. Belgyógyászati Klinika elmúlt 11 évének akut (nem promyelocytás) myeloid leukémiás eseteit elemeztük azzal a célzattal, hogy pontosabb képet kapjunk a kezelt betegpopulációról, illetve az alkalmazott kezelési modalitások eredményeiről.

Korösszetétel tekintetében a hatvan év feletti betegek aránya közel kétszeres volt. Ennek hátterében a betegség életkorral növekvő incidenciája mellett az a tényező állhat, hogy egy magas progresszivitási szintű hematológiai centrum lévén nagyszámú idős vagy relabált, refrakter beteg került felvételre progresszív ellátás keretében, továbbá klinikánkon több nemzetközi, időseket bevonó klinikai vizsgálat volt, illetve van folyamatban, ami miatt más centrumokból ideirányítják ezen betegcsoportot. A betegek többsége a WHO myelodysplasiához társult AML alcsoportjához tartozott, melynek magyarázata az említett idősebb korösszetétel, az azzal növekvő gyakoriságú jellemző 


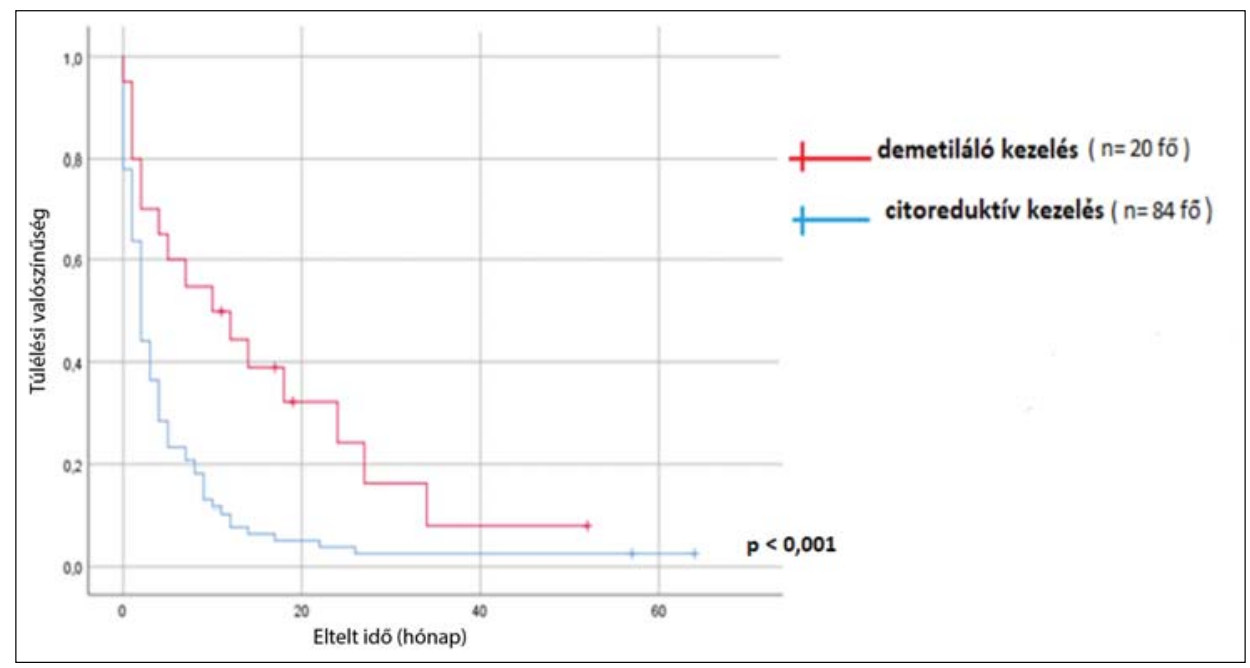

9. ábra. Összesített túlélés a palliatív kezelés típusa szerint

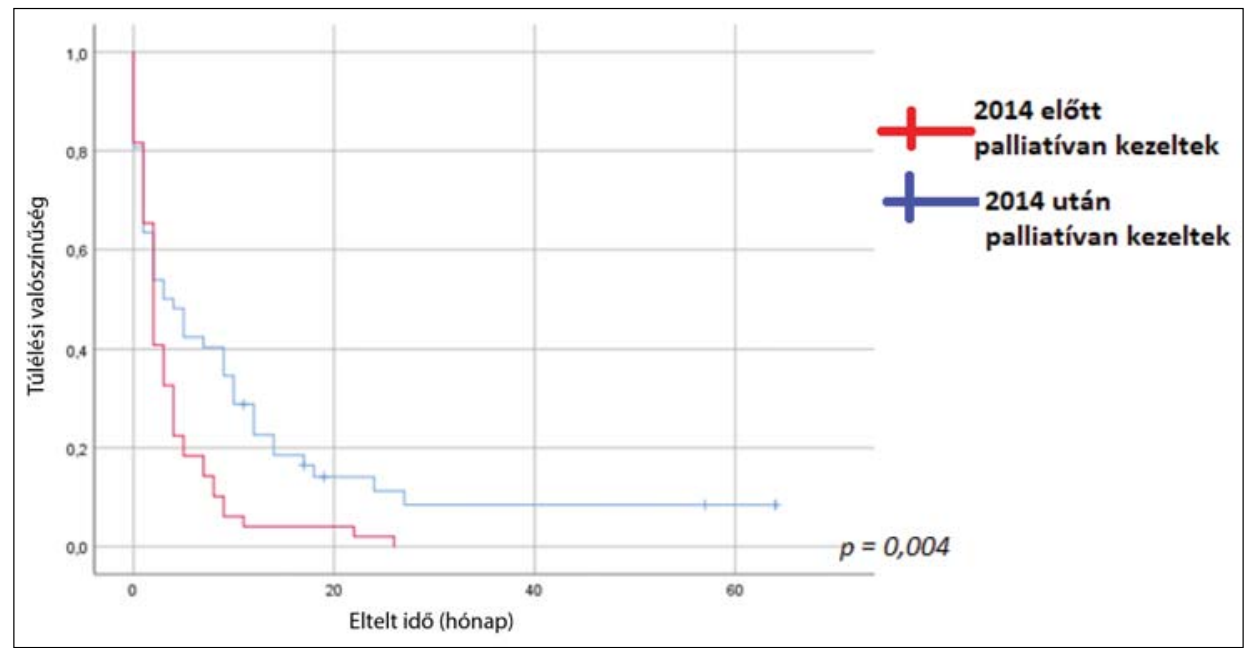

10. ábra. Összesített túlélés 2014 előtt és 2014 után palliatívan kezelt betegeinkben

karyotípusbeli eltérések és szekunder módon kialakult esetek állnak.

Osztályunk és az I. sz. Patológiai Intézet régóta fennálló hatékony együttmüködése révén nagy számban voltak elérhetőek a betegek patológiai vizsgálatainak eredményei. Az egyes ELN csoportok túlélési mutatói kissé elmaradnak beteganyagunkban az irodalomban leírtaktól, de a közöttük talált szignifikáns különbségek a Klinikán kezelt betegek körében is igazolták a karyotípus és a molekuláris genetikai eltérések alapján létrehozott csoportok prognózist hosszú távon meghatározó jelentőségét. A komplett remissziót elérők aránya a nemzetközi átlagokkal összehasonlítva csak a kedvező kórjóslatú csoportban maradt el kissé a várttól (CR: 86\% vs. 95\%) [13].

A 60 év feletti betegek az irodalmi arányokkal egybevágóan, 30\%-ban részesültek kuratív célú nagy intenzitású kemoterápiában, összességében a nemzetközi átlaghoz mérten jó eredménnyel, azaz az indukciós kezelésre alkalmas betegek kiválasztása első megközelítésben megfelelönek tünik [14]. A 70 év feletti betegek alcsoportjában azonban a kisszámú kuratívan kezelt esetből is csak 29\%-ban értünk el komplett remissziót, így tapasztalatunk szerint ebben a korcsoportban - bár az intenzív kezelés lehetőségét kizárni nem lehet - a betegek nagy többségében a palliatív vagy alacsony intenzitású demetiláló kezeléstől várhatunk terápiás előnyt $[15,16]$. A fenti adatok rávilágítanak arra is, hogy fejlesztenünk kell a nagy dózisú indukciós kezelésre alkalmas idős betegek felmérésének algoritmusait. Míg a betegséggel összefüggő faktorok (kedvező vagy kedvezőtlen prognosztikai csoport) meghatározása jól kidolgozott rendszer, a beteggel összefüggő paraméterek felmérésére még nincs standardizált módszer. A szociális-támogató háttér felmérése, illetve a geriátriai állapotfelmérő pontozási rendszerek segítséget nyújthatnak, de egyértelmü nemzetközi ajánlás nincs, így a döntés gyakran a kezelő hematológusok klinikai tapasztalata alapján történik $[14,17,18]$.

$\mathrm{Az}$ idős, elesett betegek kezelési lehetőségei korábban csak a csekély hatékonyságú citoreduktív terápiára korlátozódtak. A 2014-től elérhető demetiláló kezeléssel túl- 
élésükben radikális változás ugyan nem, de elfogadható toxicitás mellett egyértelmü javulás figyelhető meg.

A Klinikán kezelt, majd őssejt-transzplantáción átesett betegeket a nemzetközi tendenciákkal egyezve főként HLA-azonos vagy jó egyezést mutató idegen donorral transzplantálták. A túlélésük kissé elmarad a hasonló korú és donorú őssejtátültetettetekéhez képest, melynek hátterében részben a komplett remisszió és őssejt-transzplantáció között eltelt relatíve megnövekedett időintervallum (átlagosan 7 hónap) állhat [12, 19, 20].

Eredményeink tehát az irodalomban közölt adatokhoz közelítenek, de törekednünk kell a mutatók további javítására. Az utóbbi két évben nyolc új szert törzskönyveztek az AML kezelésében, melyek közül az FLT3-gátlószer midostaurint és bcl2-gátló venetoclaxot már jó tapasztalatokkal alkalmaztuk. Az IDH1-gátló ivosidenib, és az IDH2-gátló enasidenib törzskönyvezésével az IDH1- és IDH2-mutációk kimutatása is felértékelődött: a Semmelweis Egyetem I. sz. Patológiai Intézetében a relabáló AML-es betegeknél már rutinvizsgálat. Az FLT3-mutációt hordozó betegekben a midostaurin első vonalbeli alkalmazása mellett a reftakter/relabáló AML-ben engedélyezett gilteritinibbel növelhető meg a túlélés. A fentiek mellett a liposzomális daunorubicin-cytarabin (CPX351), az ismét engedélyezett gemtuzumab ozogamycin, illetve a Hedgehog-útvonalat gátló glasdegib jelenthet új reményt a betegek számára [21-24]. A transzplantációs központtal való szorosabb együttmüködéssel és megfelelő koordinációval az allogén őssejt-transzplantációra váró betegek eredményeiben is javulás várható. A diagnosztikai palettán a jövőben nagyobb szerepet kap a minimális reziduális betegség (MRD) meghatározása. Korábban a diagnóziskor elvégzett genetikai vizsgálatok, illetve a terápiára adott hematológiai válasz volt a posztremiszsziós kezelés megválasztásának alapja. Ennek tapasztalható hiányosságait pótolhatja az MRD meghatározása és követése, mellyel pontosabban definiálhatjuk majd az allogén transzplantációra javasolt betegek körét, és csökkenthetjük a hematológiai relapszusok arányát [25-27].

Nyilatkozat: A cikk nem jelent meg más folyóiratban és nem áll publikáció alatt. Az adatok egy része bemutatásra került a Society of Hematologic Oncology 2019-es konferenciáján. A szerzők a szerzői útmutatót elolvasták. A cikk végleges változatát valamennyi szerző elolvasta és jóváhagyta.

Érdekeltségek: A szerzőknek nincsenek érdekeltségeik.

Anyagi támogatás: A közlemény elkészítéséhez a szerzők anyagi támogatásban nem részesültek.

Szerzői munkamegosztás: R.A. - adatgyüjtés, statisztika, közlemény megírása; K.Sz., B.Cs. - FLT3-ITD allélterhelés meghatározása archív mintákból, közlemény megírása; N.Zs. és D.J. - közlemény megírása; T.I. - statisztika, adatértékelés, közlemény megírása.

Köszönetnyilvánítás: Köszönetet mondunk dr. Sári Eszternek, a Dél-pesti Centrumkórház, Hematológiai és Ős- sejt-transzplantációs Osztály munkatársának az adatgyüjtéshez nyújtott segítségéért.

\section{Irodalom}

[1] Shallis RM, Wang R, Davidoff A, et al. Epidemiology of acute myeloid leukemia: Recent progress and enduring challenges. Blood Rev. 2019; 36: 70-87.

[2] Noone AM HN, Krapcho M, et al. SEER Cancer Statistics Review 1975-2015. April 2018; National Cancer Institute. Bethesda, MD.

[3] Arber DA, Orazi A, Hasserjian R, et al. The 2016 revision to the World Health Organization classification of myeloid neoplasms and acute leukemia. Blood. 2016; 127: 2391-2405.

[4] Osman AEG, Anderson J, Churpek JE, et al. Treatment of acute promyelocytic leukemia in adults. J Psychosoc Oncol Res Pract. 2018; 14: 649-657.

[5] Döhner H, Estey E, Grimwade D, et al. Diagnosis and management of AML in adults: 2017 ELN recommendations from an international expert panel. Blood. 2017; 129: 424-447.

[6] Ward PS, Patel J, Wise DR, et al. The common feature of leukemiaassociated IDH1 and IDH2 mutations is a neomorphic enzyme activity converting $\alpha$-ketoglutarate to 2-hydroxyglutarate. Cancer Cell 2010; 17: 225-234.

[7] Krizsán S, Dénes Z, Gángó A, et al. Analysis of recurrent genetic abnormalities in acute myeloid leukemia in the context of novel targeted therapies. [Visszatérő genetikai eltérések vizsgálata akut myeloid leukémiában az új célzott terápiák tükrében.] Hematológia-Transzfuziológia 2019; 52: 96-105. [Hungarian]

[8] Marchesi F, Annibali O, Cerchiara E, et al. Cytogenetic abnormalities in adult non-promyelocytic acute myeloid leukemia: A concise review. Crit Rev Oncol Hematol. 2011; 80: 331-346.

[9] Estey EH. Acute myeloid leukemia: 2019 update on risk-stratification and management. Am J Hematol. 2018; 93: 1267-91.

[10] Juliusson G, Antunovic P, Derolf Å, et al. Age and acute myeloid leukemia: real world data on decision to treat and outcomes from the Swedish Acute Leukemia Registry. Blood. 2009; 113: 4179-87.

[11] Slade M, Fakhri B, Savani BN, et al. Halfway there: the past, present and future of haploidentical transplantation. Bone Marrow Transplant. 2016; 52: 1-6.

[12] D'Souza AFC. Current uses and outcomes of hematopoietic cell transplantation (HCT): CIBMTR summary slides available at https://www.cibmtr.org. 2018.

[13] Mrózek K, Marcucci G, Nicolet D, et al. Prognostic significance of the European Leukemia Net Standardized System for reporting cytogenetic and molecular alterations in adults with acute myeloid leukemia. J Clin Oncol. 2012; 30: 4515-23.

[14] Podoltsev NA, Stahl M, Zeidan AM, et al. Selecting initial treatment of acute myeloid leukaemia in older adults. Blood Rev. 2017; 31: 43-62.

[15] Kantarjian H, Ravandi F, O'Brien S, et al. Intensive chemotherapy does not benefit most older patients (age 70 years or older) with acute myeloid leukemia. Blood 2010; 116: 4422-29.

[16] Oran B, Weisdorf DJ. Survival for older patients with acute myeloid leukemia: a population-based study. Haematologica 2012; 97 : 1916-24.

[17] Klepin HD, Geiger AM, Tooze JA, et al. Geriatric assessment predicts survival for older adults receiving induction chemotherapy for acute myelogenous leukemia. Blood 2013; 121: 4287-94.

[18] Rao AV. Fitness in the elderly: how to make decisions regarding acute myeloid leukemia induction. Hematology Am Soc Hematol Educ Program 2016 (1); 339-347.

[19] Savani AA, Ka BN. Hematopoietic stem cell transplantation for acute myeloid leukemia: A review. Hematol Oncol Stem Cell Ther. 2017; 10: 245-254.

[20] Canaani J, Beohou E, Labopin M, et al. Trends in patient outcome over the past two decades following allogeneic stem cell transplan- 
tation for acute myeloid leukaemia: an ALWP/EBMT analysis. J Intern Med. 2019; 285: 407-418.

[21] Tárkányi I. Acute myeloid leukaemia in adults: therapeutic possibilities today and new agents in the future. [Az akut mieloid leukémia felnőttkorban: kezelési lehetőségeink ma és új ágensek a jövőben.] Magy Onkol. 2017; 61: 29-35.

[22] Short NJ, Kantarjian H, Ravandi F, et al. Emerging treatment paradigms with FLT3 inhibitors in acute myeloid leukemia. The Adv Hematol. 2019; 10: 2040620719827310.

[23] Cerrano M, Itzykson R. New treatment options for acute myeloid leukemia in 2019. Curr Oncol Rep. 2019; 21: 16.
[24] Guerra VA, DiNardo C, Konopleva M. Venetoclax-based therapies for acute myeloid leukemia. Best Pract Res Clin Haematol. 2019; 32: 145-153.

[25] Percival MM, Estey EH. Current treatment strategies for measurable residual disease in patients with acute myeloid leukemia. Cancer 2019; 125: 3121-30.

[26] Jongen-Lavrencic M, Grob T, Hanekamp D, et al. Molecular minimal residual disease in acute myeloid leukemia. $\mathrm{N}$ Engl J Med. 2018; 378: 1189-99.

[27] Voso MT, Ottone T, Lavorgna S, et al. MRD in AML: The role of new techniques. Front Oncol. 2019; 9: 655

A cikk a Creative Commons Attribution 4.0 International License (https://creativecommons.org/licenses/by/4.0/) feltételei szerint publikált Open Access közlemény, melynek szellemében a cikk bármilyen médiumban szabadon felhasználható, megosztható és újraközölhető, feltéve, hogy az eredeti szerző és a közlés helye, illetve a CC License linkje és az esetlegesen végrehajtott módosítások feltüntetésre kerülnek. (SID_1) 